\title{
RESEARCH PAPER \\ A potential nutritional modifier for predicting primary productivity of Pinus radiata in New Zealand using a simplified radiation-use efficiency model
}

\author{
Horacio E. Bown ${ }^{1}$, Euan G. Mason ${ }^{2}$, Michael S. Watt ${ }^{3}$, and Peter W. Clinton ${ }^{3}$ \\ ${ }^{1}$ Facultad de Ciencias Forestales, Universidad de Chile, P.O. Box 9206, Santiago, Chile. \\ ${ }^{2}$ School of Forestry, University of Canterbury, Private Bag 4800, Christchurch, New Zealand. \\ ${ }^{3}$ Scion, PO Box 29237, Christchurch, New Zealand.
}

\begin{abstract}
H.E. Bown, E.G. Mason, M.S. Watt, and P.W. Clinton. 2013. A potential nutritional modifier for predicting primary productivity of Pinus radiata in New Zealand using a simplified radiation-use efficiency model. Cien. Inv. Agr. 40(2): 361-374. The 3-PG (Physiological Principles in Predicting Growth) radiation-use efficiency model has been widely used and tested for predicting the primary productivity of forests all over the world. This radiation-use efficiency model accounts for plant nutrition through a user-defined dimensionless fertility parameter $\left(f_{\mathrm{N}}\right)$ that determines the effects a unit of radiation. Currently, this fertility parameter has to be entered by the user based on intuition or experience. The goal of this study was to propose a fertility modifier $\left(f_{\mathrm{N}}\right)$ for the radiation-use efficiency family of models based on soil chemical and physical variables. We determined gross- and net-primary productivity for a set of 10 intensively measured mini-plots of Pinus radiata D. Don on the South Island of New Zealand and then fitted a fertility modifier, $f_{\mathrm{N}}$, to the set of plots using a simplified radiationuse efficiency model. Fitted $f_{\mathrm{v}}$ values were correlated to soil physical and chemical variables. The nutritional modifier, $f_{\mathrm{N}}$, significantly increased with the soil $\mathrm{N}(\%)$ and decreased with the soil C:N ratio, and both, soil $\mathrm{N}$ and the $\mathrm{C}: \mathrm{N}$ ratio, were measured in the upper $10 \mathrm{~cm}$ of soil $\left(f_{\mathrm{N}}=1.32-0.04 \mathrm{C}: \mathrm{N}+0.99 \mathrm{~N}, \mathrm{r}^{2}=0.73, \mathrm{P}=0.009\right)$. If confirmed, this relationship may prove useful to estimate the fertility modifier of radiation-use efficiency models (e.g., 3-PG) for Pinus radiata plantations in New Zealand. However, caution should be exercised for sites where mineral nutrients other than nitrogen limit productivity.
\end{abstract}

Key words: Nutritional modifier, Pinus radiata, primary productivity, radiation-use efficiency, soil C/N, soil N.

\section{Introduction}

Mensurational forest models describe historical growth patterns in order to forecast the future

Received September 20, 2012. Accepted February 22, 2013. Corresponding author: hbown@uchile.cl development of stands (Proe et al., 1994). These models are appropriate when future stand and environmental conditions are similar to those of the past. However, intensive silviculture, genetically improved material and global environmental change have caused present conditions to be different than those of the past and also are likely to 
further change conditions in the future (Kimmins et al., 1990; Johnsen et al., 2001).

Physiological forest models, in contrast, are based on a more mechanistic understanding of physiological processes and can predict productivity over a wider range of environmental conditions (Landsberg and Gower, 1997; Johnsen et al., 2001; Landsberg, 2003). However, the general application of physiological models to forest management has been restricted by the lack of precise data, the complex calibration required to operate these models, and an incomplete understanding of key physiological processes (Mäkelä et al., 2000; Johnsen et al., 2001). Despite the fact that mensurational growth and yield models may provide more accurate growth and yield predictions, physiological models play a key role in understanding the growth potential and limiting factors of a site, as well as the biological consequences of management decisions, and may help in finding gaps where new research could be developed (Kimmins et al., 1990).

Hybrid models combine the predictive power and robustness of mensurational growth and yield models with the flexibility of physiological models, providing enhanced biological realism yet requiring fewer parameters than physiological models (Kimmins et al., 1990; Mäkelä et al., 2000; Landsberg, 2003). Hybrid models can be used to predict growth and yield and explore the effects of management decisions on forest stands (Landsberg, 2003). The hybrid approach, compared to mensurational and physiological approaches, may better meet the particular needs of a broader range of decision-makers, from forest managers to politicians and scientists.

Primary productivity is determined from light interception, conversion efficiency and the process of the allocation of carbohydrates to different functions and components within the plant (Stenberg et al., 1994). There is a family of models, known as radiation-use efficiency models, for which the hybrid approach fits particularly well. These models are based on the results of Monteith (1977) who found a strong positive relationship between crop productivity and absorbed photosynthetically active radiation (400 to $700 \mathrm{~nm}$ wavelength) in Great Britain, providing a simple yet powerful framework for the development of models based on the radiation-use efficiency concept.

Within the radiation-use efficiency family of models, 3-PG (Physiological Principles in Predicting Growth) has been widely used and tested for predicting the primary productivity of forests (Landsberg and Waring, 1997, Landsberg et al. 2003, Feikema et al. 2010, Bryars et al. 2013). This particular model represents the relationship between photosynthetically active solar radiation absorbed by forest canopies $\left(\phi_{\mathrm{pa}}\right)$ and the gross primary productivity by forests $\left(P_{\mathrm{G}}\right)$ :

$P_{\mathrm{G}}=\alpha_{\mathrm{c}} \Sigma \phi_{\mathrm{pa}} \min \left\{f \theta, f_{\mathrm{D}}\right\} f_{\mathrm{T}} f_{\mathrm{N}} f_{\mathrm{A}}$

where $\alpha_{c}$ is the canopy quantum efficiency (default: $0.055 \mathrm{~mol} \mathrm{CO}_{2}$ mol- $^{-1}$ quanta) and $f_{\mathrm{i}}$ are the modifying factors reducing the effectiveness of a unit of $\phi_{\mathrm{pa}}$ as a result of soil water deficit $(\theta)$, the vapor pressure deficit of the air $(\mathrm{D})$, temperature $(\mathrm{T})$, fertility (N) and age (A) (Landsberg and Hingston, 1996; Landsberg and Waring, 1997). The modifiers are dimensionless with values between zero (no growth) and unity (no environmental constraints). Because both soil water and air vapor pressure deficits affect stomatal conductance, only the most limiting of these two factors, $f \theta$ or $f_{\mathrm{D}}$, is included in the calculation (i.e., $\min \left\{f \theta, f_{\mathrm{D}}\right\}$ ). The result of multiplying $\phi_{\mathrm{pa}}$ by the modifiers can be interpreted as the utilizable radiation by plants. The model uses the ratio of net $\left(P_{\mathrm{N}}\right)$ to gross $\left(P_{\mathrm{G}}\right)$ primary productivity (carbon use efficiency, $C_{\mathrm{pp}}$ ), which has been shown to be conservative for forests $(0.45 \pm 0.05)$ to estimate $P_{\mathrm{N}}$ from $P_{\mathrm{G}}$ (Landsberg and Waring, 1997).

Carbon partitioning to different tree components in 3-PG is determined based on allocation coefficients derived from allometric equations relat- 
ing the mass of different tree components to one another. The model accounts for plant nutrition through a biomass partitioning mechanism and a user-defined fertility parameter $\left(f_{\mathrm{N}}\right)$, proportionally allocating more $\mathrm{C}$ to roots with lower values of $f_{\mathrm{N}}$ (Landsberg and Waring, 1997). This empirical approach has been used as a consequence of an incomplete understanding of the mechanisms that govern carbon allocation and nutrient uptake, mobilization and retranslocation (Landsberg, 1986; Landsberg and Waring, 1997; Coops et al., 1998), which are seen as major challenges for future model development (Raison and Myers, 1992; Waring et al., 1998; Johnsen et al., 2001; Landsberg 2003). Methods for estimating the fertility parameter $\left(f_{\mathrm{N}}\right)$ have not yet been developed, which is arguably the weakest feature of the 3-PG model (Bryars et al. 2013).

This paper proposes a fertility modifier $\left(f_{\mathrm{N}}\right)$ for the radiation-use efficiency family of models. Specifically, it intends (i) to fit $f_{\mathrm{N}}$ to observed values of gross primary productivity for a set of intensively measured plots using a simplified radiation-use efficiency model (Eq. 1), (ii) to model the response of $f_{\mathrm{N}}$ to soil chemical and physical variables, and (iii) to discuss whether a model such as this could be applied to other forest conditions. Correlating $f_{\mathrm{N}}$ with soil chemical and physical variables, if these correlations exist, would provide some evidence that soil fertility can be represented in radiation-use efficiency models. Using gross-primary productivity instead of biomass or wood production as a dependent variable allowed us to use a simplified radiation-use efficiency model and eliminate all downstream physiological parameters used by 3-PG, which otherwise would need to be assumed, adding extra uncertainty to the estimation of $f_{\mathrm{N}}$.

\section{Materials and methods}

\section{Trial location and carbon balance estimation}

We previously described a set of 10 small plots located in five sites in a wide soil and environ- mental gradient on the South Island of New Zealand (Bown et al., 2011). These plots were intensively measured every month for a year to determine gross and net primary productivity and their partitioning above- and below-ground, which we used to predict the fertility rating $f_{\mathrm{N}}$. The sites were Rai Valley $\left(41^{\circ} 12.637^{\prime} \mathrm{S}, 173^{\circ}\right.$ $28.006^{\prime}$ E), Golden Downs ( $41^{\circ} 30.451^{\prime} \mathrm{S}, 172^{\circ}$ 53.962' E), Tekapo (44 $2.226^{\prime} \mathrm{S}, 170^{\circ} 25.565^{\circ}$ E), Longwoods ( $\left.46^{\circ} 9.857^{\prime} \mathrm{S}, 167^{\circ} 57.053^{\prime} \mathrm{E}\right)$ and Catlins ( $\left.46^{\circ} 24.495^{\prime} \mathrm{S}, 169^{\circ} 28.014^{\prime} \mathrm{E}\right)$ (Figure 1). According to the US soil taxonomy (Soil Survey Staff, 1999; Ross et al., 2009), the soils at all of the sites were Inceptisols, except for Longwoods, where the soil was Andisol. At each site, there was a control and a fertilized plot. Each plot was small in size $(3 \times 3 \mathrm{~m}, 7 \times 7$ trees $)$, contained nine measurement trees spaced at 0.5 $\times 0.5 \mathrm{~m}\left(40,000\right.$ trees $\left.\mathrm{ha}^{-1}\right)$ and was surrounded by a two-row buffer. All of the sites were planted with one-year-old Pinus radiata D. Don seedlings in the winter of 2001 and harvested at the end of winter 2005. Fertilization was applied in all of the plots at the time of planting in doses of 18 , $6,16.8,4.8,1.2$ and $4.8 \mathrm{~kg} \mathrm{ha}^{-1}$ of total elemental $\mathrm{N}, \mathrm{P}, \mathrm{K}, \mathrm{S}, \mathrm{Mg}$ and $\mathrm{Ca}$, respectively. Fertilization (Hydrogreen; $14 \%$ N, 5\% P, 15\% K, 1\% S, 1.2\% $\mathrm{Mg}$ ) was then applied in prescribed plots in the spring of every year between 2002 to 2004 at 612 g per plot $\left(9 \mathrm{~m}^{2}\right)$, which was equivalent to 95,34 , 102,7 and $8 \mathrm{~kg} \mathrm{ha}^{-1}$ of elemental N, P, K, S and $\mathrm{Mg}$, respectively. The nitrogen in the fertilizer was provided as $44 \% \mathrm{~N}^{-\mathrm{NO}_{3}}{ }^{-}$and $56 \% \mathrm{~N}^{-} \mathrm{NH}_{4}^{+}$.

A comprehensive set of soil physical and chemical properties was taken within each plot following the methods fully described in Watt et al. (2005). Measurements of air temperature and relative humidity were taken from sensors installed on a 3-m tower located adjacent to the experimental plots. A tipping bucket rain gauge positioned on top of the tower was used to measure abovecanopy rainfall. Estimates of solar radiation were provided by the National Institute of Water and Atmospheric Research (NIWA). Volumetric water content $(0-30 \mathrm{~cm})$ was measured monthly using 


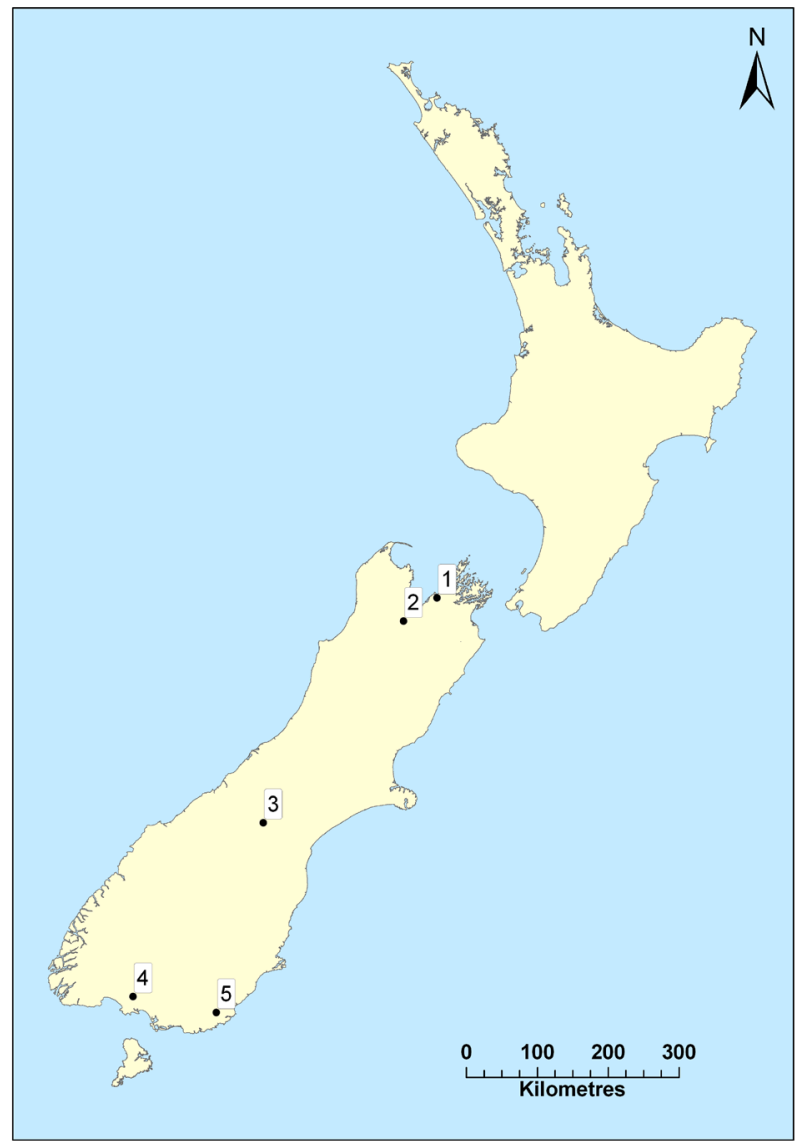

Figure 1. Locations of the experimental sites on the South Island of New Zealand. The sites are Rai Valley ( $\left.41^{\circ} 12.637 \mathrm{~S}, 173^{\circ} 28.006 \mathrm{E}\right)(1)$, Golden Downs (41 $\left.30.451^{\prime} \mathrm{S}, 172^{\circ} 53.962^{\prime} \mathrm{E}\right)(2)$, Tekapo (44 ${ }^{\circ}$ $\left.2.226^{\prime} \mathrm{S}, 170^{\circ} 25.565^{\prime} \mathrm{E}\right)(3)$, Longwoods (46 $\left.9.857^{\prime} \mathrm{S}, 167^{\circ} 57.053^{\prime} \mathrm{E}\right)(4)$ and Catlins $\left(46^{\circ} 24.495^{\prime} \mathrm{S}\right.$, $169^{\circ} 28.014^{\prime}$ E) (5).

a soil auger in all of the study plots during the fourth year after planting, which ended August 31, 2005 (see more details in Bown et al., 2011). Average values of volumetric water content were assumed to reflect the water balance during the month when the samples were taken in each plot and were used to calculate $f_{\theta}$ without the need of a water balance model.

Five trees per plot were harvested during September 2005 to fit allometric equations for stem, branch, foliage and root biomass as explained by ground line diameter. Ten current-year fascicles and ten older fascicles were randomly selected per tree, and the total hemi-surface area of needles was determined based on the water volume displacement method described by Johnson (1984). Projected leaf area can be obtained by dividing total leaf area $(2 \times$ hemi-surface area) by $\pi$ (Grace, 1987). The leaf area to mass ratio $(M)$ was determined by dividing hemi-surface leaf area by oven-dried fascicle mass. Average values for $M( \pm 1$ standard deviation) were $10.3 \pm 0.9$ and $8.7 \pm 0.3 \mathrm{~m}^{2} \mathrm{~kg}^{-1}$ for current year and older foliage, respectively. The leaf area index was calculated as leaf mass (from allometric equations) times the leaf area to mass ratio divided by the plot size.

Gross- (GPP) and net-primary productivity (NPP) and the partitioning of GPP into above-ground plant respiration (APR), above-ground net-primary productivity (ANPP) and total below-ground carbon flux (TBCF) were determined at the plot level using a carbon budget approach (Giardina 
Table 1. Description and source of parameters of a simplified radiation-use efficiency model used in the fitting of the fertility rating $\left(f_{\mathrm{N}}\right)$ to control and fertilized mini-plots of Pinus radiata at five sites on the South Island of New Zealand.

\begin{tabular}{|c|c|c|c|c|}
\hline Description & $\begin{array}{c}\text { 3-PG } \\
\text { symbol }\end{array}$ & Units & $\begin{array}{l}\text { Parameter } \\
\text { value }\end{array}$ & Parameter Source \\
\hline \multicolumn{5}{|l|}{ Canopy structure and processes } \\
\hline Extinction coefficient for absorption of PAR by canopy & $\mathrm{K}$ & - & 0.5 & Feikema et al. (2010) \\
\hline Canopy quantum efficiency & $\alpha_{c}$ & molC mol PAR ${ }^{-1}$ & 0.065 & Bown et al. (2009) \\
\hline \multicolumn{5}{|l|}{ Temperature modifier (fT) } \\
\hline Minimum temperature & $T_{\min }$ & ${ }^{\circ} \mathrm{C}$ & 0 & Walcroft et al. (1997) \\
\hline Optimum temperature & $T_{\mathrm{opt}}$ & ${ }^{\circ} \mathrm{C}$ & 20 & Walcroft et al. (1997) \\
\hline Maximum temperature & $T_{\max }$ & ${ }^{\circ} \mathrm{C}$ & 32 & Walcroft et al. (1997) \\
\hline \multicolumn{5}{|l|}{ VPD modifier $(f \mathrm{D})$} \\
\hline Constant in VPD modifier for canopy conductance & $k_{\mathrm{g}}$ & - & 0.5 & Feikema et al. 2010 \\
\hline \multicolumn{5}{|l|}{ Soil water modifier $\left(f_{\theta}\right)$} \\
\hline Moisture ratio deficit which gives $f_{\theta}=0.5$ & $c_{\theta}$ & - & 0.7 & $\begin{array}{l}\text { Landsberg and } \\
\text { Waring (1997) }\end{array}$ \\
\hline Power of moisture ratio deficit in $f_{\theta}$ & $n_{\theta}$ & - & 9 & $\begin{array}{l}\text { Landsberg and } \\
\text { Waring (1997) }\end{array}$ \\
\hline
\end{tabular}

Only those parameters of 3-PG used in the fitting of $f_{\mathrm{N}}$ to observed values of gross-primary productivity are reported in this table. All other downstream parameters required by $3-\mathrm{PG}$ to calculate values other than GPP were disregarded in the analysis.

and Ryan, 2002; Giardina et al., 2003) for the year ending on August 31, 2005. GPP was calculated as the sum of APR, ANPP and TBCF, while NPP was calculated as GPP minus autotrophic respiration. For more details, see Bown et al. (2011).

\section{Fitting $f_{\mathrm{N}}$ for each plot}

Values for the fertility rating $\left(f_{\mathrm{N}}\right)$ were fitted to the actual values of gross-primary productivity (GPP, $\mathrm{gC} \mathrm{m}^{-2}$ year $^{-1}$ ) that were estimated for the control and fertilized mini-plots of $P$. radiata described in Bown et al. (2011). Values of $f_{\mathrm{N}}$ were fitted using Eq. 1 using monthly steps based on leaf area, and climatic and water balance data recorded for each plot. Values of absorbed photosynthetically active solar radiation $\left(\phi_{\mathrm{pa}}\right)$ were calculated from solar radiation $\left(\phi_{\mathrm{p}}\right)$, the leaf area index $(L)$ and Beer's Law $\left(\phi_{\mathrm{pa}}=\phi_{\mathrm{p}}\left(1-\mathrm{e}^{-k L}\right)\right.$ considering a continuous canopy, where $k$ is the light-extinction coefficient (for parameter values see Table 1). The following equations were used for the modifying factors (from 3-PG):

a. Vapor-pressure deficit modifier, $f_{D}=e^{-k_{g} D}$, where $D$ is a monthly average vapor pressure deficit $(\mathrm{kPa})$ and $k_{\mathrm{g}}$ is the stomatal sensitivity to $D$. b. Soil water deficit modifier, $f_{\theta}=1 /\left(1+\left(1-r_{\theta}\right) /\right.$ $\left.\mathrm{c}_{\theta}\right)^{\mathrm{n} \theta}$, where $\mathrm{c}_{\theta}$ and the power $\mathrm{n}_{\theta}$ take different values for different soil types and $r_{\theta}$ is the moisture ratio. As the volumetric water content was measured monthly in all plots $\left(\theta_{\mathrm{i}}\right)$, the moisture ratio was calculated as the fractional available water: $\mathrm{r}_{\theta}=\left(\theta_{\mathrm{i}}-\theta_{\min }\right) /\left(\theta_{\max }\right.$ $\left.-\theta_{\min }\right)$, where $\theta_{\min }$ and $\theta_{\max }$ are the minimum and maximum volumetric water contents recorded over the measurement year.

c. Temperature Modifier,

$f_{T}=\left(\frac{T_{a}-T_{\min }}{T_{o p t}-T_{\min }}\right)\left(\frac{T_{\max }-T_{a}}{T_{\max }-T_{o p t}}\right)^{\frac{T_{\max }-T_{o p t}}{T_{o p t}-T_{\min }}}$

where $T_{\min }, T_{\text {opt }}$ and $T_{\max }$ are minimum, optimum and maximum temperatures for growth, and $T_{\mathrm{a}}$ are the mean monthly air temperatures. Values of $T_{\min }, T_{\text {opt }}$ and $T_{\max }$ were determined from Walcroft et al. (1997).

Once plot values for $f_{\mathrm{D}}, f_{\theta}$ and $f_{\mathrm{T}}$ were determined, $f_{\mathrm{N}}$ was calculated as the value that would equal the observed versus the estimated gross primary productivity $\left(P_{\mathrm{G}}\right)$ for a particular plot. The age modifier $\left(f_{\mathrm{A}}\right)$ was not considered in the calcula- 
Table 2. Gross- and net-primary productivity, climate, 3-PG modifying factors, soil physical and chemical properties associated with control (C) and fertilized (F) mini-plots of Pinus radiata at five sites on the South Island of New Zealand. Soil analyses were conducted on samples extracted from mineral soil at a depth of $0-10 \mathrm{~cm}$. Water balance was determined as the average monthly volumetric water content $(\theta)$. Climate and plant variables are reported for the year ending on August 31, 2005. Acronyms: PAR, photosynthetically active radiation (400-700 nm); VPD, air vapor pressure deficit; $\theta_{\mathrm{i}}$, volumetric water content; $r$, fractional available water; APAR, absorbed PAR; GPP, gross-primary productivity; NPP, net primary productivity.

\begin{tabular}{|c|c|c|c|c|c|c|c|c|c|c|c|}
\hline \multirow[b]{2}{*}{ Variable } & \multirow[b]{2}{*}{ Unit } & \multicolumn{2}{|c|}{ Rai Valley } & \multicolumn{2}{|c|}{ Golden Downs } & \multicolumn{2}{|c|}{ Tekapo } & \multicolumn{2}{|c|}{ Catlins } & \multicolumn{2}{|c|}{ Longwoods } \\
\hline & & $\mathrm{C}$ & $\mathrm{F}$ & $\mathrm{C}$ & $\mathrm{F}$ & $\mathrm{C}$ & $\mathrm{F}$ & $\mathrm{C}$ & $\mathrm{F}$ & $\mathrm{C}$ & $\mathrm{F}$ \\
\hline \multicolumn{12}{|l|}{ Climate } \\
\hline PAR & $\left(\mathrm{MJ} \mathrm{m}^{-2}\right)$ & 2549 & 2549 & 2878 & 2878 & 2320 & 2320 & 2102 & 2102 & 2081 & 2081 \\
\hline Rain & $(\mathrm{mm})$ & 1918 & 1918 & 1409 & 1409 & 609 & 609 & 1190 & 1190 & 1290 & 1290 \\
\hline Air temp. & $\left({ }^{\circ} \mathrm{C}\right)$ & 13.5 & 13.5 & 13.7 & 13.7 & 11.0 & 11.0 & 10.4 & 10.4 & 8.2 & 8.2 \\
\hline VPD & $(\mathrm{kPa})$ & 0.56 & 0.56 & 0.60 & 0.60 & 0.58 & 0.58 & 0.45 & 0.45 & 0.35 & 0.35 \\
\hline$\theta_{\mathrm{i}}$ & $\left(\mathrm{m}^{3} \mathrm{~m}^{-3}\right)$ & 0.24 & 0.23 & 0.26 & 0.25 & 0.14 & 0.13 & 0.24 & 0.23 & 0.24 & 0.22 \\
\hline$r_{\theta}$ & $\left(\mathrm{m}^{3} \mathrm{~m}^{-3}\right)$ & 0.83 & 0.78 & 0.81 & 0.75 & 0.41 & 0.34 & 0.81 & 0.83 & 0.77 & 0.78 \\
\hline \multicolumn{12}{|l|}{ Plant } \\
\hline Rooting depth & $(\mathrm{mm})$ & 778 & 386 & 368 & 462 & 539 & 456 & 401 & 427 & 330 & 415 \\
\hline Leaf area index & $\left(m^{2} m^{-2}\right)$ & 9.3 & 7.9 & 4.0 & 6.8 & 5.0 & 6.9 & 5.3 & 7.4 & 2.8 & 3.6 \\
\hline APAR & $\left(\mathrm{MJ} \mathrm{m}^{-2}\right)$ & 2525 & 2499 & 2490 & 2784 & 2134 & 2245 & 1955 & 2051 & 1559 & 1736 \\
\hline GPP & $\left(\mathrm{kg} \mathrm{C} \mathrm{m}^{-2}\right)$ & 5.65 & 5.14 & 3.98 & 5.52 & 3.30 & 3.40 & 4.46 & 4.67 & 3.21 & 4.41 \\
\hline NPP & $\left(\mathrm{kg} \mathrm{C} \mathrm{m}^{-2}\right)$ & 2.78 & 2.52 & 2.24 & 3.17 & 1.65 & 1.70 & 2.43 & 2.51 & 1.73 & 3.01 \\
\hline NPP/GPP & $\%$ & 0.49 & 0.49 & 0.56 & 0.58 & 0.50 & 0.50 & 0.54 & 0.54 & 0.54 & 0.68 \\
\hline Radiation-use efficiency & $\left(\mathrm{g} \mathrm{C} \mathrm{MJ}^{-1}\right)$ & 2.24 & 2.06 & 1.60 & 1.98 & 1.55 & 1.52 & 2.28 & 2.28 & 2.06 & 2.54 \\
\hline Temperature modifier & - & 0.85 & 0.85 & 0.85 & 0.85 & 0.71 & 0.71 & 0.72 & 0.72 & 0.60 & 0.60 \\
\hline VPD modifier & - & 0.96 & 0.96 & 0.96 & 0.99 & 0.99 & 0.96 & 0.96 & 0.96 & 0.96 & 0.99 \\
\hline Water modifier & - & 1.00 & 1.00 & 1.00 & 1.00 & 0.51 & 0.46 & 1.00 & 1.00 & 1.00 & 1.00 \\
\hline Nutritional modifier & - & 0.73 & 0.67 & 0.48 & 0.62 & 0.92 & 1.17 & 0.85 & 0.87 & 0.81 & 0.99 \\
\hline \multicolumn{12}{|l|}{ Soil physical } \\
\hline USDA texture class & - & clay & clay & clay loam & clay loam & silt loam & silt loam & clay loam & clay loam & silty clay & silty clay \\
\hline Sand & $(\%)$ & 20 & 20 & 26 & 26 & 23 & 23 & 34 & 34 & 5 & 5 \\
\hline Silt & $(\%)$ & 34 & 34 & 42 & 42 & 62 & 62 & 39 & 39 & 46 & 46 \\
\hline Clay & $(\%)$ & 46 & 46 & 31 & 31 & 15 & 15 & 27 & 27 & 49 & 49 \\
\hline Bulk density & $\left(\mathrm{g} \mathrm{cm}^{-3}\right)$ & 0.99 & 0.99 & 1.15 & 1.15 & 0.92 & 0.92 & 0.79 & 0.79 & 0.47 & 0.47 \\
\hline Part. density & $\left(\mathrm{g} \mathrm{cm}^{-3}\right)$ & 2.68 & 2.68 & 2.53 & 2.53 & 2.53 & 2.53 & 2.51 & 2.51 & 2.22 & 2.22 \\
\hline Pen. resistance & $(\mathrm{MPa})$ & 0.77 & 0.77 & 1.23 & 1.23 & 0.78 & 0.78 & 0.68 & 0.68 & 0.71 & 0.71 \\
\hline Tot. porosity & $(\%, v / v)$ & 63 & 63 & 55 & 55 & 64 & 64 & 69 & 69 & 79 & 79 \\
\hline Macroporosity & $(\%, \mathrm{v} / \mathrm{v})$ & 24 & 24 & 14 & 14 & 17 & 17 & 22 & 22 & 18 & 18 \\
\hline \multicolumn{12}{|l|}{ Soil chemical } \\
\hline Total C & $(\%)$ & 4.27 & 5.06 & 6.07 & 5.62 & 3.98 & 4.13 & 7.01 & 6.53 & 26.74 & 24.47 \\
\hline Total N & $(\%)$ & 0.23 & 0.23 & 0.25 & 0.23 & 0.29 & 0.28 & 0.31 & 0.34 & 0.85 & 0.80 \\
\hline $\mathrm{C}: \mathrm{N}$ ratio & - & 18.6 & 21.9 & 24.6 & 24.5 & 13.9 & 14.6 & 22.3 & 19.3 & 31.3 & 30.5 \\
\hline $\mathrm{pH}$ & - & 4.8 & 4.4 & 4.5 & 4.4 & 5.1 & 5.1 & 4.6 & 4.5 & 4.2 & 4.0 \\
\hline CEC & $\left(\mathrm{cmol} \mathrm{kg}^{-1}\right)$ & 20.15 & 20.42 & 16.63 & 17.18 & 17.77 & 17.28 & 17.40 & 17.05 & 42.89 & 45.77 \\
\hline Exch. Ca & $\left(\mathrm{cmol} \mathrm{kg}^{-1}\right)$ & 5.21 & 3.07 & 1.67 & 1.50 & 5.89 & 4.06 & 1.00 & 1.19 & 9.27 & 6.58 \\
\hline Exch. Mg & $\left(\mathrm{cmol} \mathrm{kg}^{-1}\right)$ & 2.97 & 2.23 & 0.92 & 1.01 & 1.19 & 1.09 & 0.89 & 1.30 & 3.93 & 4.11 \\
\hline Exch. K & $\left(\mathrm{cmol} \mathrm{kg}^{-1}\right)$ & 0.75 & 0.90 & 0.49 & 0.73 & 0.56 & 1.05 & 0.32 & 0.84 & 0.44 & 1.22 \\
\hline Exch. $\mathrm{Na}$ & $\left(\mathrm{cmol} \mathrm{kg}^{-1}\right)$ & 0.31 & 0.34 & 0.18 & 0.06 & 0.18 & 0.17 & 0.27 & 0.34 & 0 & 0.68 \\
\hline Sum bases & $\left(\mathrm{cmol} \mathrm{kg}^{-1}\right)$ & 9.2 & 6.5 & 3.3 & 3.3 & 7.8 & 6.4 & 2.5 & 3.7 & 13.6 & 12.6 \\
\hline Base sat. & $(\%)$ & 45.9 & 32.0 & 19.6 & 19.2 & 44.0 & 36.9 & 14.3 & 21.6 & 31.7 & 27.5 \\
\hline Olsen P & $\left(\mu \mathrm{g} \mathrm{g}^{-1}\right)$ & 3 & 10 & 3 & 26 & 13 & 30 & 31 & 65 & 3 & 16 \\
\hline Bray P & $\left(\mu \mathrm{g} \mathrm{g}^{-1}\right)$ & 4 & 28 & 12 & 67 & 37 & 109 & 49 & 106 & 4 & 36 \\
\hline Inorg. P & $\left(\mu \mathrm{g} \mathrm{g}^{-1}\right)$ & 74 & 148 & 42 & 162 & 143 & 227 & 299 & 409 & 44 & 202 \\
\hline Org. P & $\left(\mu \mathrm{g} \mathrm{g}^{-1}\right)$ & 438 & 383 & 280 & 273 & 601 & 587 & 598 & 657 & 477 & 492 \\
\hline Total P & $\left(\mu \mathrm{g} \mathrm{g}^{-1}\right)$ & 512 & 531 & 322 & 435 & 744 & 814 & 898 & 1065 & 520 & 694 \\
\hline
\end{tabular}


tions as the plants were the same age (four years old) with a $f_{\mathrm{A}}$ value close to 1 . Some additional parameters used in the fitting are presented in Table 1. Significant relationships between $f_{\mathrm{N}}$ and soil chemical properties were tested through a multiple regression analysis. All of the statistical analyses were undertaken using the R System for Statistical Computing (R Development Core Team, 2010. R: A language and environment for statistical computing. Vienna, Austria: R Foundation for Statistical Computing).

\section{Results}

\section{Climatic and edaphic variation across sites}

The climate at the study sites exhibited large differences. The mean annual air temperature varied 1.7 -fold from approximately $8-10^{\circ} \mathrm{C}$ in Southland (sites 4 and 5, see Figure 1) to 13-14 $\mathrm{C}$ in the Nelson region (sites 1 and 2). Mean air temperatures in Tekapo (site 3) were intermediate compared to other sites $\left(11^{\circ} \mathrm{C}\right)$, but this site exhibited the lowest monthly minimums among sites while monthly maximums were similar to those of Golden Downs (site 2) and Rai Valley (site 1). The annual rainfall ranged threefold from $609 \mathrm{~mm}$ at Tekapo to $1918 \mathrm{~mm}$ at Rai Valley (Table 2).

Selected sites exhibited large differences in soil physical and chemical properties. The greatest differences in physical properties were found in textural classes, particularly the sand fraction (ranging 7-fold) and the clay fraction (ranging 3 -fold), as well as in the bulk density (ranging more than twofold). Soil chemical properties were strongly influenced by site and, to a lesser extent, by fertilization (Table 2). Variation across sites was considerable for exchangeable $\mathrm{Na}$ (16-fold), exchangeable $\mathrm{Ca}$ (7-fold), Olsen and Bray P (5- to 8-fold), carbon (6-fold), nitrogen (4-fold), exchangeable Mg (4-fold), CEC (3-fold) and the $\mathrm{C}: \mathrm{N}$ ratio (2-fold). Fertilization significantly increased the exchangeable K (1.9-fold), Olsen P (2.7-fold), Bray P (3.3-fold), Inorganic P (1.9-fold) and total P (1.2-fold) and slightly decreased the $\mathrm{pH}$ (by $2 \%$ ) (Table 2).

\section{Estimating the fertility rating $f_{N}$}

Comparisons on the influence of fertility on productivity are difficult because environmental determinants such as rainfall, solar radiation, temperature and vapor pressure deficit may confound the interpretation of nutrient availability on productivity (Mead, 1984). Therefore, some low nutrient availability sites (e.g., Golden Downs) may exhibit greater productivity than high nutrient availability sites (e.g., Tekapo). This confounding effect may be removed by fitting the fertility parameter $\left(f_{\mathrm{N}}\right)$ using Eq. 1 to known values of gross primary productivity and climatic and water balance data (Table 2). Based on this approach, we found the highest fertility ratio for Tekapo (i.e., $f_{\mathrm{N}}$ equal to 0.92 and 1.17 for the control and fertilized mini-plot, respectively) compared to Golden Downs (i.e., $f_{\mathrm{N}}$ equal to 0.48 and 0.62 for the control and fertilized mini-plot, respectively). We also found that the low productivity observed in the high fertility Tekapo site was due to water limitations; i.e., the water modifier $f_{\theta}$ was 0.51 and 0.46 for the control and fertilized mini-plots, respectively, compared to higher $f_{\theta}$ values (less water limitations) for all other conditions (Figure 2). As expected, the temperature modifier $f_{\mathrm{T}}$ (and primary productivity) decreased with latitude while the VPD modifier was generally high for all sites (Table 2). All values of the nutritional modifier ranged between 0-1 except for the fertilized plot at Tekapo $\left(f_{\mathrm{N}}=1.17\right)$. We accepted this value despite it being outside the range $0-1$ in all subsequent analyses, recognizing that the parameterization of the model did not produce perfect scaling. 


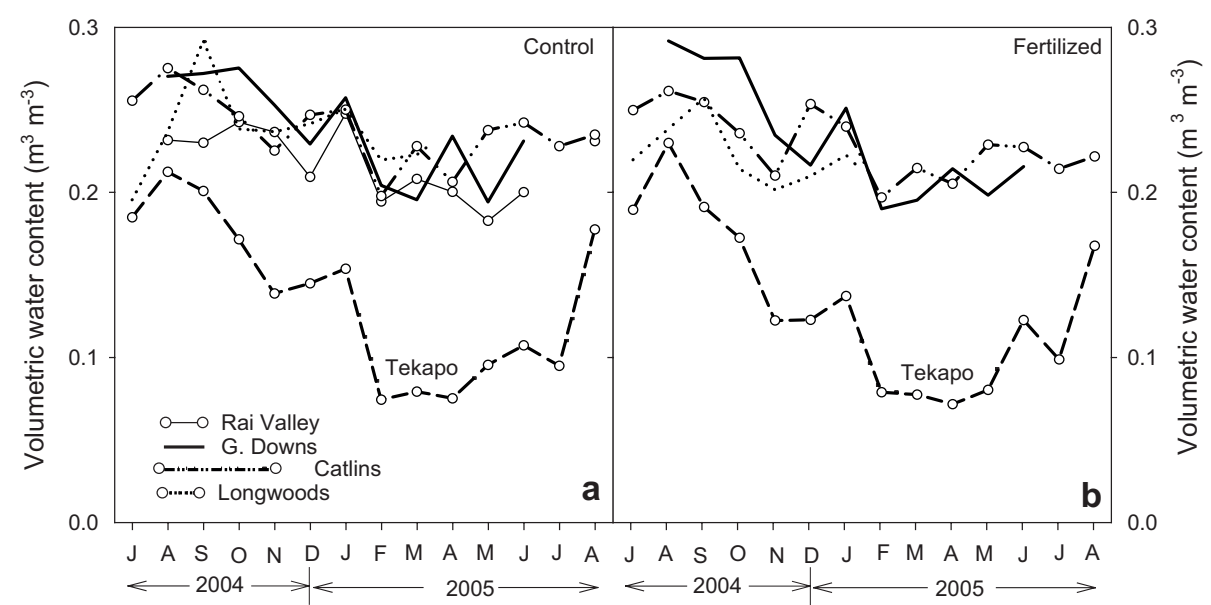

Figure 2. Seasonal fluctuations in volumetric water content in control (a) and fertilized (b) mini-plots of Pinus radiata at five sites on the South Island of New Zealand.

\section{Fertility rating versus soil physical and chemical variables}

The fertility rating, $f_{\mathrm{N}}$, was positively correlated to the soil $\mathrm{N}$ and inversely correlated to the soil C:N ratio in the upper $10 \mathrm{~cm}$ of soil (i.e., $f_{\mathrm{N}}$ $=1.32+0.99 \mathrm{~N}(\%)-0.04 \mathrm{C}: \mathrm{N}, \mathrm{r}^{2}=0.73, \mathrm{P}=$ 0.009). The overall model and all its coefficients were highly significant $(\mathrm{P} \leq 0.01)$ (Figure 3 ). All other regression models of $f_{\mathrm{N}}$ as explained by soil chemical variables, other than the soil $\mathrm{N}$ and the soil C:N ratio, as well as soil physical variables, were not significant.

Bearing in mind that Longwoods exhibited a high leverage for soil $\mathrm{N}$ and soil $\mathrm{C} / \mathrm{N}$ (Figures 4c, d), we tested the strength of this relationship by removing the outlier points from the Longwoods site. The new relationship was still significant (i.e., $f_{\mathrm{N}}=1.12+1.53 \mathrm{~N}(\%)-0.037 \mathrm{C}: \mathrm{N}, \mathrm{r}^{2}=0.77, \mathrm{P}$ $=0.024$ ), and the coefficients were consistent in sign and similar in magnitude to the model fitted without removing the Longwoods site (i.e., $f_{\mathrm{N}}=1.32+0.99 \mathrm{~N}(\%)-0.04 \mathrm{C}: \mathrm{N}, \mathrm{r}^{2}=0.73, \mathrm{P}=$ 0.009). All coefficients except that for the soil $\mathrm{N}$ $(\mathrm{P}=0.24)$ were significant in the model without the Longwoods site. The insignificant coefficient

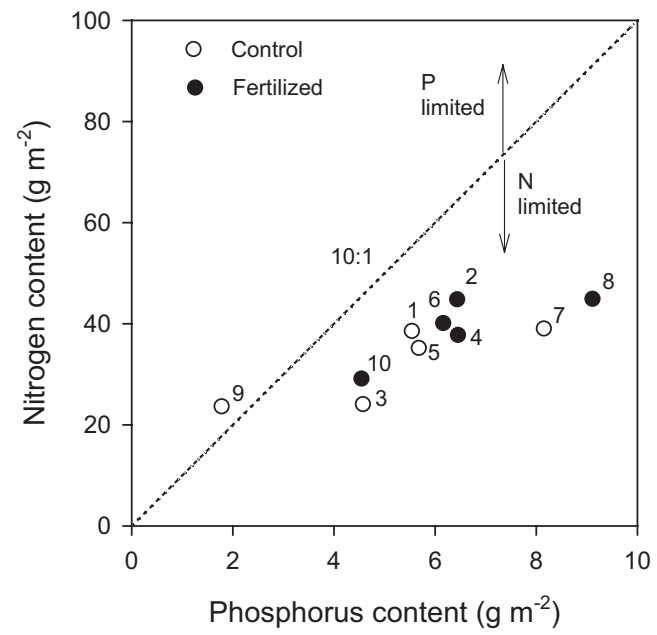

Figure 3. The relationship between above-ground biomass nitrogen and phosphorus content in control (open- symbols) and fertilized (closed-symbols) mini-plots of four-year old Pinus radiata in five sites on the South Island of New Zealand. The dotted line has a slope 10:1, separating nitrogen $(\mathrm{N}: \mathrm{P}<10)$ from phosphorus $(\mathrm{N}: \mathrm{P}$ $\left.>10 \mathrm{~g} \mathrm{~g}^{-1}\right)$ deficiencies. Plot numbers are indicated besides symbols: 1-2 Rai Valley, 3-4 Golden Downs, 5-6 Tekapo, 7-8 Catlins, 9-10 Longwoods.

for the soil $\mathrm{N}$ was most likely associated with the reduction in the degrees of freedom after removing the Longwoods site (9 compared to 7 degrees of freedom). 

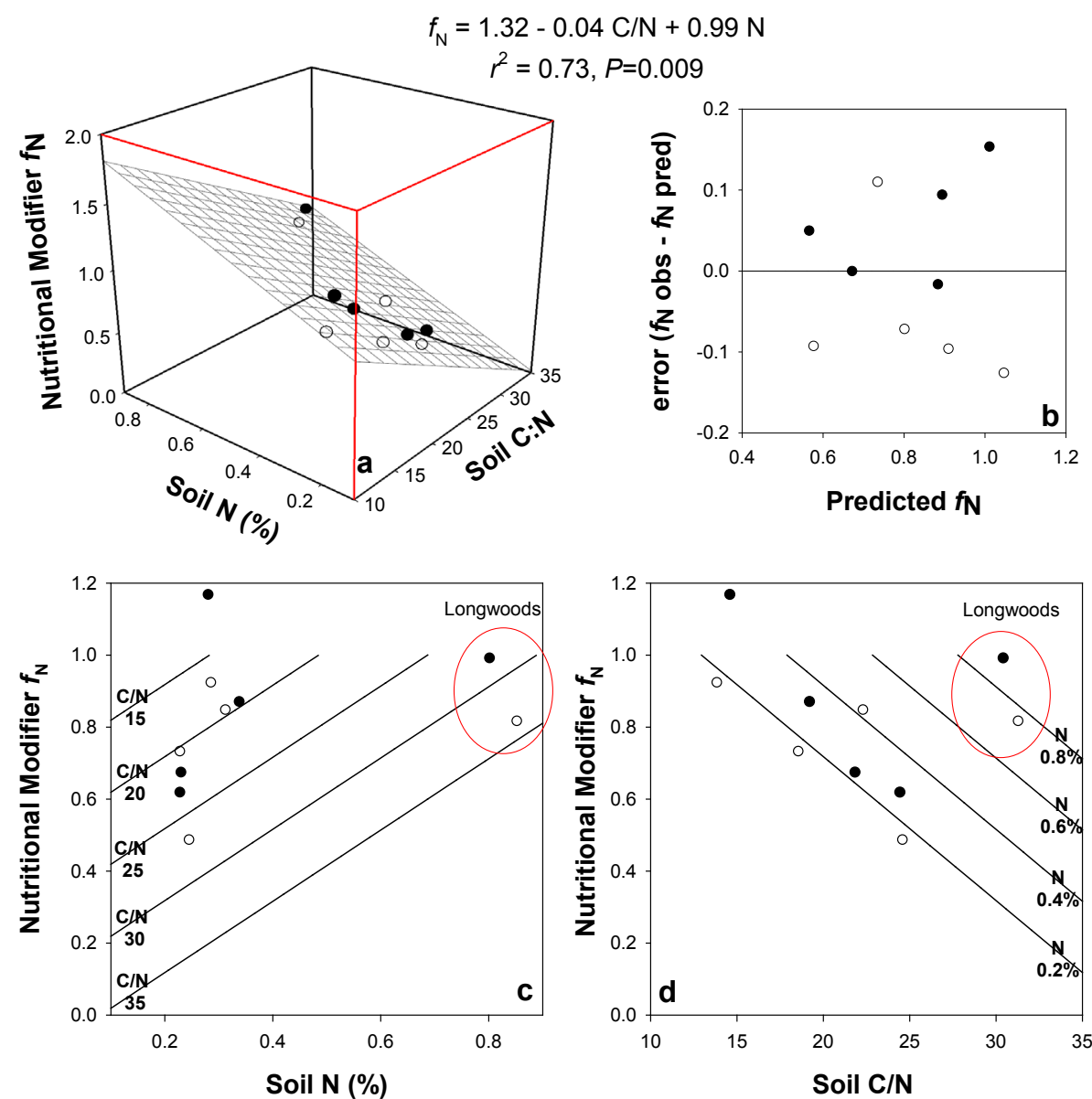

Figure 4. The relationship between the fertility ratio, soil $\mathrm{N}$ and the soil $\mathrm{C}: \mathrm{N}$ ratio in control (open-symbols) and fertilized (closed-symbols) mini-plots of four-year old Pinus radiata in five sites on the South Island of New Zealand. The fertility ratio $\left(f_{\mathrm{N}}\right)$, a unitless parameter between 0 and 1 , was fitted to actual values of GPP obtained in the field using a minimum set of parameters from 3-PG. Ellipsoids in (c) and (d) show the high leverage of the Longwoods site for soil $\mathrm{N}$ and soil $\mathrm{C} / \mathrm{N}$.

\section{Nitrogen or phosphorus deficiencies?}

The above-ground biomass $\mathrm{N}$ and $\mathrm{P}$ content at the time of harvesting (August 2005) was used to determine whether the sites were mostly N- or P- limited. A ratio of 10:1 on a mass basis (23 mole basis) may be useful for separating nitrogen $\left(\mathrm{N}: \mathrm{P} \leq 10 \mathrm{~g} \mathrm{~g}^{-1}\right)$ from phosphorus $(\mathrm{N}: \mathrm{P}>10 \mathrm{~g}$ $\left.\mathrm{g}^{-1}\right)$ deficiencies, as proposed by several authors from growth studies (Reich and Schoettle, 1988; Marschner 1995; Aerts and Chapin, 2000). The relationship between $\mathrm{N}$ and $\mathrm{P}$ content for all ten plots is presented in Figure 3, with the dotted line representing a slope of 10:1. Nine of the ten plots are below the 10:1 slope line, suggesting that these plots were mainly N- rather than P-limited. The control plot at Longwoods (plot 9) is slightly above the 10:1 line, which may indicate that this plot was at the transition between $\mathrm{N}$ to $\mathrm{P}$ limitations (Figure 3).

\section{Discussion}

Nitrogen $(\mathrm{N})$ and phosphorus $(\mathrm{P})$ are the nutrients that most frequently limit primary productivity in all ecosystems in the biosphere (Aerts and Chapin, 2000; Hall et al., 2005). This is not surprising, as $\mathrm{N}$ is a vital constituent of proteins playing an essential role in all enzymatic 
activities, $\mathrm{P}$ is involved in energy transfers in the cell, and both are important structural elements in nucleic acids (Marschner, 1995). Aerts and Chapin (2000) suggested that imbalances between these two elements may be more important than absolute amounts of either element in plants, and therefore these type of imbalances may lead to nitrogen or phosphorus deficiencies (Reich and Schoettle, 1988; Marschner, 1995; Aerts and Chapin, 2000). Knecht and Göransonn (2004) argued that the optimum ratio of nitrogen to phosphorus in terrestrial plants is similar for a wide range of species and is approximately 10 on a mass basis (i.e., 23 on a mole basis). Plots under study were mostly N-limited as indicated by a ratio of biomass $\mathrm{N}: \mathrm{P}$ content of less than 10:1 on a mass basis (Figure 3).

We found that the fertility rating, $f_{N}$, was positively correlated to the soil $\mathrm{N}$ and inversely correlated to the soil $\mathrm{C}: \mathrm{N}$ ratio in the upper $10 \mathrm{~cm}$ of soil (i.e., $f_{\mathrm{N}}=1.32+0.99 \mathrm{~N}(\%)-0.04 \mathrm{C}: \mathrm{N}, \mathrm{r}^{2}=0.73$, $\mathrm{P}=0.009)$. This result seems reasonable because primary productivity is strongly driven by $\mathrm{N}$ mineralization in the soil (Reich et al., 1997; Newman et al., 2006) and in the plant (Walcroft et al., 1997), and there is a negative relationship between $\mathrm{N}$ mineralization and the soil C: $\mathrm{N}$ ratio (McLaren and Cameron, 1996; Bengtsson et al., 2003). By transitivity it may be expected that fertility and the fertility modifier increase with soil $\mathrm{N}$ and decrease with the soil $\mathrm{C}: \mathrm{N}$ ratio as seen in Figure 4. If confirmed, this relationship may prove useful for representing nutrition in hybrid models, particularly in the 3-PG model. However, caution should be exercised for sites in which mineral nutrients other than nitrogen are limiting productivity.

Stape et al. (2004a, b, 2006) suggested using paired plots with and without fertilization to parameterize the fertility modifier required to calibrate hybrid models such as 3-PG and ProMod (Landsberg, 2003; Battaglia and Sands, 1997). They related the fertilization response of Eucalyptus plantations in Brazil with soil exchangeable $\mathrm{K}$, total $\mathrm{P}$ and cation exchange capacity with medium accuracy $\left(\mathrm{r}^{2}=0.56\right.$, $\mathrm{P} \leq 0.001$ ). Our results suggest that sites (soils), rather than fertilization treatments, are the main drivers behind fertility and the nutritional modifier $f_{\mathrm{N}}$. Therefore, it would be more advantageous to estimate gross- and net-primary productivity and its partitioning above- and below-ground for a large number of permanent sample plots (unpaired) over a wide range of soil and environmental conditions, with as few assumptions as possible, in order to correctly parameterize the nutritional modifier. We are aware that the number of plots used to parameterize the nutritional modifier in this study was modest $(\mathrm{n}=10)$, and consequently we consider our model to be a likely hypothesis to be further tested in the future, particularly if plots could be separated as N- and P-limited using stoichiometry ratios such as those presented in Figure 3.

The proposed nutritional modifier is simple and based on stable soil attributes that are routinely measured in standard soil chemical analyses, i.e., soil N and soil C:N. Kimmins and Scoullar (1984) suggested that the current state of knowledge of plant nutrition does not allow for the high resolution often used in today's tree growth models and that adopting a simpler approach to process descriptions avoiding time resolutions less than one year should be preferred. This broader approach has been followed here proposing a fertility modifier based on soil chemical attributes which do not change much over time.

Allocation theory predicts that nutrient and water stresses shift photosynthate away from leaves and stems, where carbon is used for light capture, to belowground processes, where carbon is used to support fine and coarse root growth and respiration, exudates and to sustain mycorrhizae (Raich and Nadelhoffer, 1989; Cannel and Dewar, 1994). The user-defined fertility parameter $\left(f_{\mathrm{N}}\right)$ in the current form of 3-PG allows for the partitioning of more $\mathrm{C}$ belowground, with lower values of $f_{\mathrm{N}}$ (Landsberg and Waring, 1997). This approach has been followed as a result of an incomplete understanding of the mechanisms that govern 
carbon partitioning as determined by soil fertility (Landsberg, 1986; Landsberg and Waring, 1997; Coops et al., 1998). Bown et al. (2011), working with the same plots used in this study, found that the fraction of the total below ground carbon flux (TBCF) increased with the soil C:N ratio (upper $10 \mathrm{~cm}$ ); i.e., $33 \%$ of GPP was partitioned belowground at soil C:N ratios below 17, climbing steadily for soil C:N ratios over 20 , to a likely maximum of approximately $60 \%$ of GPP for $\mathrm{C}: \mathrm{N}$ ratios over 30 (TBCF : GPP $=0.3255+$ $\left.0.5480\left(1-\mathrm{e}^{-0.1227 \mathrm{C:N}}\right)^{45.7440}\right)$. Additionally, there was no significant relationship between the C:N ratio and above-ground net primary productivity (ANPP : GPP 0.26), while above-ground plant respiration (APR) declined from approximately $43 \%$ at low $\mathrm{C}: \mathrm{N}$ ratios (a $\mathrm{C}: \mathrm{N}$ ratio below 17 ) to a minimum of approximately $21 \%$ at soil $\mathrm{C}: \mathrm{N}$ ratios of approximately 32 (APR : GPP $=0.4304$ $\left.-0.3584\left(1-\mathrm{e}^{-0.1418 \mathrm{C}: \mathrm{N}}\right)^{45.2291}\right)$. Therefore, there is consistency in the soil C:N driving the fertility modifier $f_{\mathrm{N}}$ and $\mathrm{C}$ partitioning below-ground; i.e., higher values of soil $\mathrm{C}: \mathrm{N}$ predict lower values of $f_{\mathrm{N}}$ but high values of the fraction TBCF:GPP. Consequently, the fertility rating $\left(f_{\mathrm{N}}\right)$ proposed in this study should be coupled to the calculation of the TBCF:GPP, ANPP:GPP and APR:GPP fractions exhibited in a previous paper (Bown et al., 2011) to obtain a reasonable estimation of primary productivity and its partitioning for Pinus radiata plantations in New Zealand.

The radiation use efficiency 3-PG model implicitly assumes multiplicative (independent) effects of the soil water deficit and the nutritional modifier because, according to probability theory, if two events $(\mathrm{A}$ and $\mathrm{B})$ are independent, then $\mathrm{P}(\mathrm{A} \cap \mathrm{B})=$ $\mathrm{P}(\mathrm{A}) \mathrm{P}(\mathrm{B})$. This seems to be a reasonable modeling assumption that can be illustrated by comparing two sites contrasting in water availability such as Tekapo (dry) and Rai Valley (wet). Both sites exhibited small (non-existent) growth responses to fertilization, but Tekapo was drastically limited by water and exhibited a much lower overall productivity (GPP: 5.4 cf. $3.4 \mathrm{~kg} \mathrm{C} \mathrm{m}^{-2}$ year $^{-1}$ ). Although water stress arguably reduces nutrient availability in absolute terms, the reduction in relative terms is completely accounted for by the soil water deficit modifier $\left(f_{\theta}\right)$ seen in this study and therefore does not need to be re-accounted for in the nutritional modifier $\left(f_{\mathrm{N}}\right)$. Nambiar (1990), pooling data from several studies, showed linear responses of basal area growth to $\mathrm{N}$ uptake in irrigated and non-irrigated plots of Pinus radiata near Canberra, Australia. Irrigated and nonirrigated trajectories were almost parallel to each other, suggesting that the effect of nutrient and water supply might be considered independent (additive rather than interactive). Assuming independence of processes in relative terms over long time spans (i.e., 1 year) greatly simplifies the representation of nutrition in the radiation-use efficiency model, avoiding the need to disentangle fertility and water stresses on shorter time scales.

In summary, a fertility modifier $\left(f_{\mathrm{N}}\right)$ was fitted using a simplified algorithm of 3-PG to actual values of gross-primary productivity (GPP) estimated for control and fertilized mini-plots of Pinus radiata at five sites on the South Island of New Zealand. Values of $f_{\mathrm{N}}$ increased with the soil $\mathrm{N}$ and decreased with the soil $\mathrm{C}: \mathrm{N}$ ratio in the upper $10 \mathrm{~cm}$ of soil; i.e., $f_{\mathrm{N}}=1.32+0.99 \mathrm{~N}$ (\%) - 0.04 C: $\mathrm{N}\left(\mathrm{r}^{2}=0.73, \mathrm{P}=0.009\right)$. If confirmed, this relationship may prove useful to estimate the fertility modifier of radiation-use efficiency models (e.g., 3-PG) for Pinus radiata plantations in New Zealand. However, caution should be exercised for sites in which mineral nutrients other than nitrogen are limiting productivity.

\section{Acknowledgements}

During this work the senior author was supported by SCION, the University of Canterbury, the Universidad de Chile and by a Doctoral Scholarship provided by Education New Zealand. We thank Mr. Alan Leckie, Mr. Nigel Pink, Mrs. Vicki Wilton and Mr. Lachlan Kirk for their kind advice and valuable technical skills. The experiments and measurements undertaken for this paper comply with the current laws of New Zealand. 


\section{Resumen}

H.E. Bown, E.G. Mason, M.S. Watt y P.W. Clinton. 2013. Un potencial modificador nutricional para predecir productividad primaria de Pinus radiata en Nueva Zelanda usando un modelo simplificado de eficiencia en el uso de la radiación. Cien. Inv. Agr. 40(2): 361-374. El modelo de eficiencia en el uso de la radiación 3-PG (por sus siglas en inglés: Physiological Principles in Predicting Growth) ha sido ampliamente utilizado y probado para predecir productividad primaria de bosques en todo el mundo. Este modelo considera el estado nutricional de un cultivo a través de un parámetro de fertilidad $\left(f_{\mathrm{N}}\right)$ adimensional, definido por el usuario que reduce la efectividad de una unidad de radiación en el modelo. De momento este parámetro de fertilidad es ingresado por el usuario basado en intuición o experiencia. El objetivo de este estudio consistió en proponer un modificador de fertilidad $\left(f_{\mathrm{N}}\right)$ para la familia de modelos de eficiencia en el uso de la radiación basado en variables físicas y químicas de suelos. Para lograr este objetivo, se determinó la productividad primaria bruta y neta en un conjunto de 10 mini-parcelas, medidas intensivamente, de Pinus radiata D. Don en la Isla Sur de Nueva Zelanda, posterior a lo cual se ajustó el modificador de fertilidad, $f_{\mathrm{N}}$, al conjunto de parcelas utilizando un modelo simplificado de eficiencia en el uso de la radiación. Los valores ajustados de $f_{\mathrm{N}}$ fueron correlacionados con una amplia gama de variables físicas y químicas de suelos. El modificador nutricional, $f_{\mathrm{N}}$, aumentó significativamente con la concentración de $\mathrm{N}$ en el suelo (\%) y disminuyó con la relación C:N del suelo, ambas variables medidas en los primeros $10 \mathrm{~cm}$ del suelo $\left(f_{\mathrm{N}}=1,32-0,04 \mathrm{C}: \mathrm{N}+0,99 \mathrm{~N}, \mathrm{r}^{2}=0,73, \mathrm{P}=0.009\right)$. De ser confirmada, esta relación podría demostrar ser útil para estimar el modificador de fertilidad en los modelos de eficiencia en el uso de la radiación (e.g. 3-PG) para plantaciones de Pinus radiata en Nueva Zelanda. Sin embargo, se debe tener precaución en el cálculo de este parámetro de fertilidad en sitios en los cuales nutrientes otros que nitrógeno limitan la productividad.

Palabras clave: modificador nutricional, Pinus radiata, productividad primaria, eficiencia en el uso de la radiación, relación $\mathrm{C} / \mathrm{N}$ de los suelos, $\mathrm{N}$ en el suelo

\section{References}

Aerts R., and F.S. Chapin. 2000. The mineral nutrition of wild plants revisited: A re-evaluation of processes and patterns. Advances in Ecological Research 30:1-67.

Battaglia M., and P. Sands. 1997. Modelling site productivity of Eucalyptus globulus in response to climatic and site factors. Australian Journal of Plant Physiology 24:831-850.

Bengtsson, G., P. Bengtson, and K.F. Månsson. 2003. Gross nitrogen mineralization, immobilization, and nitrification rates as a function of soil $\mathrm{C} / \mathrm{N}$ ratio and microbial activity. Soil Biology and Biochemistry 35:143-154.

Bown, H.E., E.G. Mason, P.W. Clinton, and M.S. Watt. 2009. Chlorophyll fluorescence response of Pinus radiata clones to nitrogen and phosphorus supply. Cien. Inv. Agr. 36:451-464.

Bown, H.E., M.S. Watt, P.W.Clinton, and E.G. Mason. 2011. Soil $\mathrm{C} / \mathrm{N}$ influences the carbon flux and partitioning in control and fertilized miniplots of Pinus radiata in New Zealand. Cien. Inv. Agr. 38:277-289.

Bryars, C., C. Maier, D. Zhao, M. Kane, B. Borders, R. Will, and R. Teskey. 2013. Fixed physiological parameters in the 3-PG model produced accurate estimates of loblolly pine growth on sites in different geographic regions. Forest Ecology and Management 289:501-514.

Cannell, M.G.R., and R.C. Dewar. 1994. Carbon allocation in trees: a review of concepts for modeling. Advances in Ecological Research 25 59-104.

Coops, N.C., R.H. Waring, and J.J. Landsberg. 1998. 
Assessing forest productivity in Australia and New Zealand using a physiologically-based model driven with averaged monthly weather data and satellite-derived estimates of canopy photosynthetic capacity. Forest Ecology and Management 104:113-127.

Feikema, P.M., J.D. Morris, C.R. Beverly, J.J. Collopy, T.G. Baker, and P.N. Lanea. 2010. Validation of plantation transpiration in south-eastern Australia estimated using the $3 \mathrm{PG}+$ forest growth model. Forest Ecology and Management 260:663-678.

Giardina, C.P., and M.G. Ryan 2002. Total belowground carbon allocation in a fast-growing $E u$ calyptus plantation estimated using a carbon balance approach. Ecosystems 5:487-499.

Giardina, C.P., M.G. Ryan, D. Binkley, and J.H. Fownes. 2003. Primary production and carbon allocation in relation to nutrient supply in a tropical experimental forest. Global Change Biology 9:1438-1450.

Grace, J.C. 1987. Theoretical ratio between "one-sided" and total surface area for pine needles. New Zealand Journal of Forestry Science 17:292-296.

Hall, S.R., V.H. Smith, D.A. Lytle, and M.A. Leibold. 2005. Constraints on primary producer $\mathrm{N}: \mathrm{P}$ stoichiometry along N:P supply ratio gradients. Ecology 86:1894-1904.

Johnsen K., L. Samuelson, R. Teskey, S. McNulty, and T. Fox. 2001. Process models as tools in forestry research and management. Forest Science 47:2-8.

Johnson, J.D. 1984. A rapid technique for estimating total surface area of pine needles. Forest Science 30:913-921.

Kimmins, J.P., and K.A. Scoullar. 1984. The role of modelling in tree nutrition research and site nutrient management. In: Bowen, G.D., and E.K. Nambiar (eds.). London: Academic Press. p. 463-487.

Kimmins, J.P., P.G. Comeau, and W. Kurz. 1990. Modelling the interactions between moisture and nutrients in the control of forest growth. Forest Ecology and Management 30:361-379.

Knecht, M.F., and A. Göransonn. 2004. Terrestrial plants require nutrients in similar proportions. Tree physiology 24:447-460.
Landsberg, J.J. 1986. Physiological ecology of forest production. London: Academic Press. 198 pp.

Landsberg, J.J., and F.J. Hingston. 1996. Evaluating a simple radiation/dry matter conversion model using data from Eucalyptus globulus plantations in Western Australia. Tree Physiology 16(10):801-808.

Landsberg, J.J., and S.T. Gower. 1997. Applications of physiological ecology to forest management. San Diego: Academic Press. 354 pp.

Landsberg, J.J., and R.H. Waring. 1997. A generalized model of forest productivity using simplified concepts of radiation-use efficiency, carbon balance and partitioning. Forest Ecology and Management 95:209-228.

Landsberg, J.J. 2003. Modelling forest ecosystems: State of the art, challenges, and future directions. Canadian Journal of Forest Research 33:385-397.

Landsberg, J.J., R.H. Waring, and N.C. Coops. 2003. Performance of the forest productivity model 3-PG applied to a wide range of forest types. Forest Ecology and Management 172:199-214.

Mäkelä, A., J.J. Landsberg, A.R. Ek, T.E. Burk, M. Ter-Mikaelian, G.I. Agren, C.D. Oliver, and P. Puttonen. 2000. Process-based models for forest ecosystem management: current state of the art and challenges for practical implementation. Tree Physiology 20:289-298.

McLaren, R.G., and K.C. Cameron. 1996. Soil Science: Sustainable Production and Environmental Protection. Victoria, Australia: Oxford University Press. 304 pp.

Marschner, H. 1995. Mineral nutrition of higher plants. Academic Press, London. 889 pp.

Mead, D.J. 1984. Diagnosis of nutrient deficiencies in plantations. In: Bowen, G.D., and E.K. Nambiar (eds.). London: Academic Press. p. 259-291.

Monteith, J.L. 1977. Climate and the efficiency of crop production in Britain. Philosophical Transactions of the Royal Society of London Series BBiological Sciences 281:277-294.

Nambiar, E.K. 1990. Interplay between nutrients, water, root growth and productivity in young plantations. Forest Ecology and Management 30:213-232. 
Newman, G.S., M.A. Arthur, and R.N. Muller. 2006. Above- and belowground net primary production in a temperate mixed deciduous forest. Ecosystems 9:317-329.

Proe, M.F., H.M. Rauscher, and J. Yarie. 1994. Computer simulation models and expert systems for predicting productivity decline. In: Dyck, W.J., D.W. Cole, and N.B. Comerford (eds.). Impacts of forest harvesting on long-term site productivity. 1st. ed. London: Chapman \& Hall. p. 371.

Raich, J.W., and K.J. Nadelhoffer. 1989. Belowground carbon allocation in forest ecosystems: global trends. Ecology 70:1346-1354.

Raison, R.J., and B.J. Myers. 1992. The Biology of Forest Growth experiment: linking water and nitrogen availability to the growth of Pinus radiata. Forest Ecology and Management 52:279-308. Reich, P.B., and A.W. Schoettle. 1988. Role of phosphorus and nitrogen in photosynthetic and whole plant carbon gain and nutrient use efficiency in eastern white pine. Oecologia 77:25-33.

Reich, P.B., D.F. Grigal, J.D. Aber, and S.T. Gower. 1997. Nitrogen mineralization and productivity in 50 hardwood and conifer stands on diverse soils. Ecology 78:335-347.

Ross, C.W., M.S. Watt, R.L. Parfitt, R. Simcock, J. Dando, G. Coker, P.W. Clinton, and M. Davis. 2009. Soil quality relationships with tree growth in exotic forests in New Zealand. Forest Ecology and Management 258:2326-2334.

Soil Survey Staff. 1999. Soil taxonomy: A basic system of soil classification for making and interpreting soil surveys. In: Service UNRC (ed.). 2nd ed. US Government Printing Office, Washington DC. $871 \mathrm{pp}$.

Stape, J.L., M.G. Ryan, and D. Binkley. 2004a. Testing the utility of the 3-PG model for growth of
Eucalyptus grandis $x$ urophylla with natural and manipulated supplies of water and nutrients. Forest Ecology and Management 193:219-234.

Stape, J.L., D. Binkley, and M.G. Ryan. 2004b. Eucalyptus production and the supply, use and efficiency of use of water, light and nitrogen across a geographic gradient in Brazil. Forest Ecology and Management 193:17-31.

Stape, J.L., D. Binkley, W.S. Jacob, and E.N. Takahashi. 2006. A twin-plot approach to determine nutrient limitation and potential productivity in Eucalyptus plantations at landscape scales in Brazil. Forest Ecology and Management 223:358-362.

Stenberg, P., T. Kuuluvainen, S. Kellomaki, J.C. Grace, E.J. Jokela, and H.L. Gholz. 1994. Crown structure, light interception and productivity of pine trees and stands. In: Gholz, H.L., S. Linder, and R.E. McMurtrie (eds.). Ecological Bulletins 43:20-34.

Waring R.H., J.J. Landsberg, and J. Williams. 1998. Net primary production of forests: a constant fraction of gross primary production? Tree Physiology 1998(18):129-134.

Walcroft, A.S., D. Whitehead, W.B. Silvester, and F.M. Kelliher. 1997. The response of photosynthetic model parameters to temperature and nitrogen concentration in Pinus radiata D. Don. Plant Cell and Environment 20:1338-1348.

Watt, M.S., G. Coker, P.W. Clinton, M.R. Davis, R. Parfitt, R. Simcock, L. Garret, T.W. Payn, B. Richardson, and A. Dunningham 2005. Defining sustainability of plantation forests through identification of site quality indicators influencing productivity- a national view for New Zealand. Forest Ecology and Management. 216:51-63. 